\title{
Strategy of Oyster Mushroom Cultivation in Mushroom House at Urban Village of Siumbut Baru, Sub-District of East Kisaran, District of Asahan
}

\author{
Rosdiana $^{a}$, Noni Afifah ${ }^{\mathrm{a}}$, Third Author ${ }^{\mathrm{b}}$

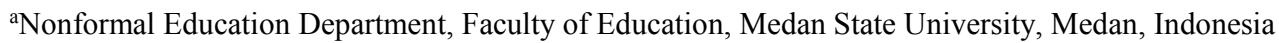

Corresponding e-mail: $\underline{\text { rosdianafip@gmail.com }}$

\begin{abstract}
The problem in this research is how the management strategy of oyster mushroom cultivation in Mushroom House, Urban Village of SiumbutBaru, sub-district of East Kisaran, District of Asahan. The purpose of this research is to find out the management strategy of oyster mushroom cultivation in Mushroom House, Urban Village of SiumbutBaru, sub-district of East Kisaran, District of Asahan. This is a descriptive qualitative research, the informant are the manager and two employees of the Mushroom House. The data were collected by interview and documentation, and analysed through: data collection, data reduction, data display, and conclusion. The results showed that the manager can develop and improve the quality of his business systematically in order to have a good management system in accordance with the management function, he can make good preparation for his business, he always choose the superior oyster mushroom seeds, he takes care of the oyster mushroom that have been cultivated, and analysed the oyster mushroom business opportunities and renewing the types of food that will be served. The interview revealed that the management strategy in improving the motivation of employees to build their own business by giving them knowledge with sincerity, give them strategy to to improve the quality of business and never give up.
\end{abstract}

Keywords: mushroom cultivation, management strategy, oyster mushroom

\section{INTRODUCTION}

One of the most popular businesses nowadays is food business. Food business, especially horticulture, is currently aimed to strengthening food self-sufficiency, increasing public incomes, and improving nutrition through food diversification. Horticulture is one of the agricultural sub-sectors that occupy an important position in contributing to the Indonesian economy. Consumption of horticultural products, such as mushrooms, mushroom farming has become attractive business in agricultural sector due to its simplicity and flexibility of cultivation and quite profitable [1]. Mushroom continues to increase in line with increasing population, increasing incomes and increasing public knowledge about nutrition and health. This is the reason that this is the right time forhorticulture farming to get serious attention, especially in the aspects of production and development of marketing system.

Mushrooms are a valuable part of the human diet and are an important food in the United States and world wide [2]. Edible mushrooms include fungi that thrive on damp decaying organic matter alone or in combination with soil [3] as it depends on nutrients obtained from dead and decaying materials [4]. Mushrooms are highly nutritious and environment friendly crops that carry numerous medicinal benefits. A literature and database review and several experiments were carried out because of the perturbing increase and exponential spreading of a major mistake thought scientific publications. Up to October 2015, more than 136 reports ensured that mushrooms contain flavonoids, however, $91 \%$ of the publications used an unspecific colorimetric method that was developed to quantify them in plants [5]. In fact Mushrooms do not contain flavonoids [4].

The cultivation of edible mushrooms carries great relevance in todays' world in the context of a burgeoning population growth and extreme pressure on the environment [6]. But advances in research on mushroom breeding and production is very limited as compared to other crops. This maybe partly due to a lack of previous knowledge of the genetics and breeding system in this crop. Classical breeding in 
mushrooms has been difficult due to the predominantly secondarily homothallic life cycle of this fungus [7].

Mushrooms also contribute in creating the diverse menu of typical Indonesian food such as tempe and tape. Mushrooms are one type of horticultural products that can be developed and directed to improve the nutritional status of the community [8]. The use of pesticides in mushroom cultivation is relatively small. Therefore, the fungus is a food that is safe for consumption. In addition to the relatively cheap price, then almost all people can afford it.

The mushrooms are advantages to grow as compared to button mushrooms. They requires no arable land for production and the abundant agriculture waste found countrywide offers opportunity for production, which in turn provides a more economical and environmentally friendly disposal system[9], and also they can easily grow in local conditions if the appropriate requirements of food and moisture for growth are available [10]. Oyster mushroom (Pleurotus ostreatus, Kummer) is the second largest commercially produced and important edible mushroom in the world market [11] after Agaricus mushrooms [3]. Oyster mushrooms have been cultivated using tree logs or containers such as shelves, boxes, bags, and bottles containing growing media [9].

In the middle of the rush of market competition for income generation, one community Urban Village of Siumbut Baru, sub-district of East Kisaran, District of Asahan opened a business in the field of food where oyster mushroom is the main ingredient however in the present study it is clearly indicated that waste paper can be used as the sole or combined with an enriched substrate for cultivation of the oyster mushroom; a valuable and highly nutrient fungal type [12]. From the observations that have been done, the mushrooms used are mushrooms from their own cultivation. The results of the cultivation is processed into various types of food and served to customers. Based on the new innovation, the people of Kisaran visit many mushroom houses every day. Increased visitors cause business owners are often out of stock of oyster mushrooms that ultimately do not satisfy visitors. Not only that, the lack of employees and small cultivation area alsogiven less attention,therefore that the management still has many shortcomings. The area of the cultivation, parking lot, and space for the visitors are still very inadequate because it still uses the area of the house manager. In addition, the manager also instill with the concept of food will be cooked if it is ordered in order to maintain customers satisfaction.

However, the consequence of this concept is that the food can be served within half an hour and sometimes even up to 1 hour after being ordered [13]. Even more, the absence of entertainment such as television, music or radio that makes visitors bored waiting. Oyster mushroom was grown on rice (Oriza sativa L.) straw alone (100:0), rice straw + peanut (Arachis hypogaea L.) shell (75:25, 50:50, and 25:75 w/w), and peanut shell alone $(0: 100)$. Responses to cultivation in boxes or bags were determined. Total nitrogen, protein, potassium, calcium, magnesium, phosphorous, and dry matter were measured. Mixing rice straw with peanut shell $(75: 25 \mathrm{w} / \mathrm{w})$ increased antioxidant capacity, magnesium, and flavonoid contents of fruit bodies [14].

\section{RESEARCH METHODS}

To see, know and describe the actual situation in detail and actual by looking at the problems and objectives of research as previously stated, the research method used in this study leads to the use of qualitative research methods [15] [16].

This research is qualitative research with descriptive analysis. This study did not use populations and samples but used the subject of the study. The term research subject refers to the person or individual or group who is made into the business unit or case unit under investigation. Research subject is the main component that has important position in a research, because in this research subject there are variables that become studies to be studied [17]. The subjects in this study are managers who also works as an employee, and two employees. So the subject of this study are three peoples which became an important source of information. The data analysis used in this research is descriptive qualitative analysis technique, where the implementation phases are data collection, data reduction, data presentation / display data, and conclusion [18] [19].

The data analysis in this qualitative research were done in a cycle and during the research process. Therefore, since the beginning of the research, researchers have to start searching data from the pattern of information, explanations, recorded information from informants and documentation [20] [21]. 


\section{RESULTS AND DISCUSSION}

Basically, the manager educational background is bachelor of education, just like the wish of his parent. However, due to his intense desire to create employment opportunities, when he graduated from college he decided to open a business [22]. Various attempts had been made but failed. Starting from opening a sate stall, selling crackers until finally he wandered to Malaysia to become TKI (Indonesian Workers). When in Malaysia he got the knowledge of oyster mushroom cultivation. He attended the course and thought to open a business of oyster mushroom cultivation in Indonesia. After three months following the course, in the same year he decided to return to Indonesia to implement the knowledge gained. He founded an oyster mushroom cultivation course in 2007. In 2008 he started an oyster mushroom cultivation business and in 2012 he innovated to process the basic ingredients of oyster mushrooms into a food in the Mushroom House.

Oyster mushrooms are foods high in protein, contain minerals and low in fat. Oyster mushroom protein content ranges from $20-40 \%$ dry weight so it is better when compared with other protein sources such as soybeans and nuts. Besides being a source of protein, vitamins and minerals, oyster mushrooms also contain compounds that act as anticancer or antitumor, antikolesterol and antioxidants. Lectin compounds in white oyster mushrooms have been proven as antitumor compounds. Therefore, it is not surprising that in Japan, the oyster mushroom is called a medicinal mushroom (hiratake) [11].

Currently Mushroom House has six employees, consisting of two men and 4 women. The opening schedule of Mushroom House is on Monday to Sunday (excluding holidays and closed Friday) starting at $13.30 \mathrm{WIB}$ to $20.30 \mathrm{WIB}$. The location of Mushroom House is on Budi Utomo Street no.116 Urban Village of Siumbut Baru, sub-district of East Kisaran, District of Asahan.

The vision of the Mushroom House is "to promote mushrooms as a source of healthy food and improve the welfare of the community". The mission of the Mushroom House are; (1) improving the quality of oyster mushrooms with the best quality, (2) opening oyster mushroom training to the community, (3) socializing the benefits of oyster mushrooms for health with a variety of processed products, and (4) increasing business in the field of community economy, especially agriculture.

The management strategy of oyster mushroom cultivation in Mushroom House is a step taken by the manager in improving the quality of his business through: having a good management system in accordance with the management function, preparing the oyster mushroom well, selecting the best oyster mushroom seeds, look after for oyster mushroom which have been cultivated, analyzing oyster mushroom business opportunities and renewing the types of food that will be served [23].

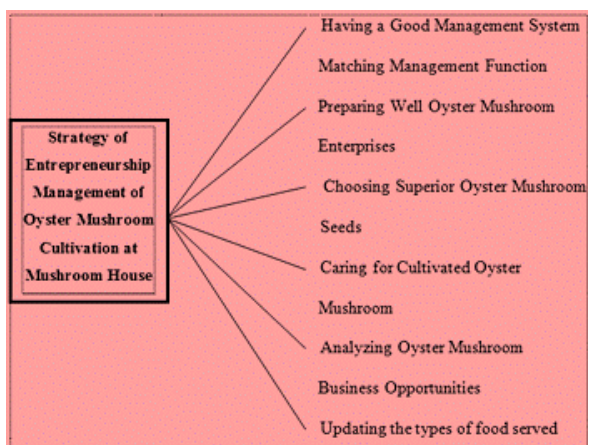

Fig.1. Strategy of Entrepreneurship Management of Oyster Mushroom Cultivation at Mushroom House

Based on "Fig 1" we know that through the strategy undertaken by the manager in improving the quality of his business, it will increase the public interest to be more familiar with the benefits of oyster mushrooms and try the processed products. It also increases the economic life of the manager and his employees. All of activities employees depend on the training, because training is an activity to improve the ability, form skills and improve the performance of individuals or groups in performing their duties by improving skills, knowledge, skills, attitudes and behaviors that are specific to the needs or job [24]. The strategies were capable of being successful innovation by interacting and cooperating with external sources, and performing certain adjustment with local condition [1].

Result of the interviews on the manager and employees of the Mushroom House, the authors can conclude that the Mushroom House manager performs a good strategy in improving the quality of his business. Where the strategy undertaken by the manager is to apply the management functions well, installing billboards at some point of the roads and start his business first, managers do door to door promotion to government offices, schools or home residents to peddle oyster mushroom cultivation made. In addition, the existence of culinary business and training as a place of people who want to taste processed oyster mushrooms or people who want to learn to cultivate oyster mushrooms.

Aspects that need to be improved in improving the quality of his business is the widening of 
cultivated land and also a comfort place to eat for the visitors. Parking land should also be wider considering the number of visitors who come. Fewer employees are also an aspect that managers need to improve. That way, it is possible to cultivate this oyster mushroom into a great effort [25].

In the previous section, researchers has describe the research result. Based on the research that is tested in data analysis, it is found that the management strategy of oyster mushroom cultivation at Rumah Mushroom are as follows: From the interviews that have been done with Mr. Ahmad Rofi'i (Manager), it can be explained that; (1) the manager applies management functions, namely planning, organizing, staffing, directing and controlling for the success of their business, (2) the manager has their own strategy to develop their business by opening a culinary business with the mushrooms processed by themselves, open training, making billboards, brochures and do door to door promotion, (3) the manager applies the theory of preparing the business properly, such as location, selection of employees, and the use of tools and materials appropriately, (4) pay full attention on the growth of oyster mushroom by keeping humidity and room temperature, (5) the manager provide knowledge about oyster mushroom cultivation to employees with hope that their employees can open their own business, and (6) the manager always updates the type of food every six months based on the consumer interest.

From the interviews conducted with Rio (employees), it can be explained that; (1) the manager always assigns employees to socialize the Mushroom House, either in the mass media, print media or personally to the public, (2) the manager is very good in preparing business, it can be seen from the selection of locations, selection of employees, and the selection of tools and materials used, (3) the manager always assigns employees to water the growth process space in order to keep the humidity and room temperature for good mushroom growth, (4) the manager always motivates employees to open their own business in order to improve the economic level of its employees, and (5) the manager always renews food type every six months basedon the consumer's interest.

From the interviews that have been done with Sri Rahayu (employee),it can be explained that; (1) the manager accepts anyone who wants to do research, community service or record hiscultivation of oyster mushroom so it will be known by society and also increase society insight, (2) the manager is very concerned about every detail of his business whether it's location, seeds or tools and materials, (3) the manager always assigns employees to water the room two times a day (morning and afternoon) to keep the humidity and room temperature growth process, and (4) the manager always provide knowledge about the cultivation of oyster mushrooms with hope that employees can open their own business.

Based on the results above, it can conclude that by knowing the management strategy of oyster mushroom cultivation, the manager can develop and improve the quality of his business systematically in order to have a good management system in accordance with management functions, prepare the business of oyster mushrooms well, choose the superior oyster mushroom seeds, take care of the oyster mushroom plants that have been cultivated, analyzing oyster mushroom business opportunities and renewing the types of food that will be served. Then the manager also plays an important role in improving employee motivation to build their own business by providing knowledge with sincerity, providing procedures to improve the quality of business and never give up spirit. If the entrepreneurial spirit is entrenched within the employees, then the manager managed to achieve the vision and mission, one of which is to prosper the community through the cultivation of oyster mushrooms.

There were many thing that so important to be repaired for the next program. The aspects that need to be improved in improving the quality of the business is the widening of cultivation land and alsoadd more place to eat for the visitors. In addition, the parking lot should also be wider considering the number of visitors who come. Employees also need addition considering the number of visitors so they dont have to wait long time before the order come.

The government should also pay more attention to potential self-sufficient enterprises in small areas so that entrepreneurs in Indonesia can improve the economy of his family without having to become unemployed or expect work in government office, because oyster mushrooms are third largest cultivated mushroom. Mushrooms (Pleurotus spp.) belonging to the class basidiomycetes and agaricaceae family [8].

It is expected that the Mushroom House employees will soon start their own business in order to create more job opportunity in the District of Asahan. That way, the unemployment rate in the Asahan area will reduce. 


\section{CONCLUSIONS}

The manager of Mushroom House has done a good business strategy in developing his business, where managers perform entrepreneurial strategy by good management in accordance with the management function, preparing the business oyster mushrooms well, choose the best seeds of oyster mushrooms, take care of oyster mushroom plants that have been cultivated, analyzing oyster mushroom business opportunities and renewing the types of food served that will be able to support the quality and quantity of its business.

Related to the vision and mission made by managers which is to improve the level of economy and community prosperity, manager tought how to cultivate oyster mushrooms to all employees, motivate employees to start their own business and never give up. Managers also provide rewards to employees who do not violate the rules and motivated to work harder.

\section{ACKNOWLEDGEMENTS}

The authors would like to thank the manager, staffs, and participants of Mushroom House that involved in this research. Thanks also to the research assistants who worked on this project: Mahfuzi Irwan within collecting the more references.

\section{REFERENCES}

[1] Febrianda, R., \& Tokuda, H. (2017). Strategy and Innovation of Mushroom Business in Rural Area Indonesia: Case Study of a Developed Mushroom Enterprise from Cianjur district, West Java, Indonesia. International Journal of Social Science Studies, 5(6), 21-29.

[2] Bose, S. (2016). Mushroom Cultivation and Marketing Strategies: An Untapped Source of Sustainable Development and Livelihood in North Bengal. Sumedha Journal of Management, 5(2), 121.

[3] Belewu,M.A, \& Belewu,K.Y. (2005) Cultivation of mushroom (Volvariella volvacea) on banana leaves. African Journal of Biotechnology,4(12), 1401-1403.

[4] Adjapong, A. O., Ansah, K. D., Angfaarabung, F., \& Sintim, H. O. (2015). Maize Residue as a Viable Substrate for Farm Scale Cultivation of Oyster Mushroom (Pleurotus ostreatus). Advances in Agriculture, 2015.

[5] Gil-Ramírez, A., Pavo-Caballero, C., Baeza, E., Baenas, N., Garcia-Viguera, C., Marín, F.
R., \& Soler-Rivas, C. (2016). Mushrooms do not contain flavonoids. Journal of Functional Foods, 25, 1-13.

[6] Gunawan,AW. (2011). Usaha Pembibitan Jamur. Jakarta: Penebar Swadaya.

[7] Chakravarty, B.(2011). Trends in cultivation and mushroom breeding. Australian Journal of AgriculturalEngineering, 2(4), 102.

[8] Agro Media, Redaksi. (2009). Bertanam Jamur Konsumsi. Jakarta: AgroMedia Pustaka.

[9] Kimenju, J. W., Odero, G. O. M., Mutitu, E. W., Wachira, P. M., Narla, R. D., \& Muiru, W. M. (2009). Suitability of locally available substrates for oyster mushroom (Pleurotus ostreatus) cultivation in Kenya. Asian Journal of Plant Sciences, 8(7), 510.

[10] Mumtaz, M. S., Khan, N. A., Rehman, A., \& Jabbar, A. (2016). Production Of Oyster Mushroom (Pleurotuspulmonarius) On Different Agriculture Wastes Combination With Lemon Grass (Cymbopogon Citratus). Pakistan Journal of Phytopathology, 28(1), 71-74.

[11] Adjapong, A. O., Ansah, K. D., Angfaarabung, F., \& Sintim, H. O. (2015). Maize Residue as a Viable Substrate for Farm Scale Cultivation of Oyster Mushroom (Pleurotus ostreatus). Advances in Agriculture, 2015.

[12] Baysal, E., Peker, H., Yalinkiliç, M. K., \& Temiz, A. (2003). Cultivation of oyster mushroom on waste paper with some added supplementary materials. Bioresource Technology, 89(1), 95-97.

[13] Sumarsih,S.(2015). Bisnis Bibit Jamur Tiram. Jakarta: Penebar Swadaya.

[14] Salmalian, N., Peyvast, G., \& Olfati, J. A. (2016). Amendments for Cultivation of Oyster Mushroom in Boxes or Plastic Bags. International Journal of Vegetable Science, 22(2), 115-120.

[15] Basrowi \& Suwandi. (2008). Memahami Penelitian Kualitatif. Jakarta: Rineka Cipta

[16] Bungin,B.(2006). Analisis Data Penelitian Kualitatif. Jakarta: RajaGrafindo Persada.

[17] Creswell, J. W., \& Poth, C. N.(2017). Qualitative inquiry and research design: Choosing among five approaches. Sage publications.

[18] Moleong,L. (2014). Metodologi Penelitian Kualitatif, Edisi Revisi. Bandung: Remaja Rosdakarya

[19] Sugiyono. (2012). Metode Penelitian Pendidikan (Pendekatan Kuantitatif, Kualitatif, dan $R \& D$ ). Bandung: Alfabeta 
[20] Sugiyono. (2010). Metode Penelitian Pendidikan (Pendekatan Kuantitatif, Kualitatif, dan $R \& D$ ). Bandung: Alfabeta

[21] Sugiyono. (2015). Metode Penelitian Pendidikan (Pendekatan Kuantitatif, Kualitatif, dan $R \& D$ ). Bandung: Alfabeta

[22] Easin, M. N., Ahmed, R., Alam, M. S., Reza, M. S., \& Ahmed, K. U. (2017). Mushroom Cultivation as a Small-Scale Family Enterprise for the Alternative Income Generation in Rural Bangladesh. International Journal of Agriculture, Forestry and Fisheries, 5(1), 1.

[23] Gunawan,AW. (2011). Usaha Pembibitan Jamur. Jakarta: Penebar Swadaya.

[24] Irwan, M. (2017). Evaluasi Program Pelatihan Keterampilan Mengolah Limbah Kertas Semen Pada Pusat Kegiatan Belajar Masyarakat (PKBM) Cahaya Kota Binjai, Propinsi Sumatera Utara (Doctoral dissertation, UNY).

[25] Corrêa, R. C. G., Brugnari, T., Bracht, A., Peralta, R. M., \& Ferreira, I. C. (2016). Biotechnological, nutritional and therapeutic uses of Pleurotus spp.(Oyster mushroom) related with its chemical composition: A review on the past decade findings. Trends in Food Science \& Technology, 50, 103-117. 